\title{
Poets/Next They'll Want To Be Loved
}

\section{Arthur Oberg}

Dear Jo Jo Jones,

Being a poetry editor is a crappy job.

It could drive a man to drink, if he weren't

already there.

Send more poems later in the century.

We might have some space then.

Keep in touch, and keep the keys dancing.

Love and sorry,

ALK

To begin with, the history of modern poetry is difficult to chart. If there is a tradition, and I believe there is, it might read-from the moon-spoon-June school of verse to the womb-tomb school. Or like, the pun is coming back. Are there any questions or comments?

\section{Dear Editor,}

Next you'll be telling me you don't like me.

I have, too, read Cummings and Pound. And I'm cancelling my subscription to your magazine. (Long letter to follow.)

In anger,

j. a. a., , , gh

$$
\text { * * }
$$

Sylvia Plath is taking her head out of the oven and beginning another poem. Berryman, in this clip, is jumping back onto the bridge, putting his hand back 
at his side, and folding it into himself. Dreaming another opus posthumous poem. There is, the music sticks, another music.

Dear Kanga,

From one poet to another, poetry stinks.

This morning, I was reading Ginsberg puzzling

over Hart Crane's pizzle, musing how if someone had

grabbed it, everything might have been different.

Like the HISTORY OF AMERICAN POETRY, I ask???? Next,

they'll be guessing what a room in the cellar would

have done to Emily Dickinson's dashes, or to the history

of the hymn stanza in American verse. I visited

Amherst three times, and each time the cellars were

pretty dark and damp. In the houses that had cellars, that is.

What are you up to, to shift the metaphor???

Write when you can clear your desk.

FX

Dear GG, we'd like you to know

we do like you so

but our funds have been/CUT

Dear old contributor,

You once wrote in another style. We liked your other style. We published you when you wrote poems in that other style.

What are you doing now? Milking a purple cow? Jacking off? Have we developed six bad ears? Anyway, this is just one opinion (THREE AS ONE). Send more when you write, again, in the old style.

(A last thought-your old, clean style reminded us of Scandinavian weaving.)

Once yours,

The patient troika

And I thought of Pound giving it to Eliot. Here is YOUR WASTE LAND, YOUR REAL WASTE LAND, HE SAID. And I thought of Marianne Moore chopping her poem, "Poetry," down, down to a few lines. I thought of memorizing the earlier version, with elephants and toads. And I cried. 
Postal rates are again going up. First, it was the price of fruits, mostly citrus. Then it was the blue piping, inside, on 747 planes. So now, it's postage stamps I need for shooting my mss. across the lonely states. Last night, my first dream after falling to sleep, was of POSTAGE STAMP GRANTS. Unfortunately, my old aunt Rita insisted on waking me up to fix a 2 A. M. leak downstairs, and just, I swear to you, when they were announcing me the first winner.

The Alaska Liquor Store . . . Grubs . . The Not So Square Review . . . Adrift . . . More Haiku . . . next thing, they'll be starting some new little magazine called FUCK YOU/A SCATTERING OF THE ARTS.

Dear ART,

I want fourteen or fifteen minutes of you.

Can you get hold of a tape recorder? Let me go backI have been asked to edit a fully-funded project called little black box. You will be immortal on tape.

Can I count on you? I think the post office has some special rate for sending tapes less than fifty miles. Maybe they won't know Coastal Bluff is more than fifty miles from where you sleep. Hello to those passing through. Is Seattle really for gulls???

Fritz

\section{Dear LACKLOVE,}

I know this is going to sound fatuous, but

I am going to say it anyway. Editors have sent back my own poems. They liked them but couldn't take them. And couldn't exactly say why. I am afraid I must say that to you.

From a reluctant chair, LLLLLLLLLL

Vow to me one thing-that you will go in fear of slant rhyme. Full rhyme tickles the ear. And it stays with you, and with your imaginary reader (over your shoulder), for a long, long time.

Seattle (where the big

birds fly) 